\title{
Toothbrush: A Favorable Media for Bacterial Growth
}

Rajiv Saini, Varun Kulkarni

\begin{abstract}
Introduction: In this era of stem cell transplantation, tissue engineering and piezosurgery, it is important to consider the toothbrush as a source of potential pathogens. As toothbrush plays an important everyday role for personal oral hygiene and effective plaque removal. Oral cavity incubates diversity of microorganisms; therefore it is not surprising that some of these microorganisms were transferred to toothbrush during use. Presence of nutrients, epithelial debris and oral secretions make the toothbrush a favorable media for numerous bacterial growths.
\end{abstract}

Aim: The main aim of this study was to evaluate the microbial flora predominantly present in toothbrushes.

Materials and methods: Samples of 150 different used toothbrushes from healthy population were taken randomly for microbial analysis. Samples of toothbrushes were put in Robertson cooked meat (RCM) media for both aerobic and anaerobic microbial recognition. Inoculation was done on blood agar and MacConkey's agar plate and culture plates were incubated for 24 hours.

Results: Fifty-four samples showed facultative anaerobes growth, i.e. Streptococcus mutans, Alpha-hemolytic streptococci, coagulase negative Staphylococci (CONS) and diphtheroids. Sixty-six samples showed polymicrobial etiology and 30 showed purely anaerobic bacteria, i.e. Bacteroides, Lactobacilli.

Conclusion: Toothbrush is thus considered a potential biohazard for reintroduction of microorganisms in the oral cavity. New oral hygiene devices like Dental Air Force home dental cleaning system will emerge as true alternative for toothbrush.

Keywords: Toothbrush, Dental Air Force, Microbial growth.

How to cite this article: Saini R, Kulkarni V. Toothbrush: A Favorable Media for Bacterial Growth. Int J Experiment Dent Sci 2013;2(1):27-28.

\section{Source of support: Nil}

Conflict of interest: None declared

\section{INTRODUCTION}

Toothbrush plays an important role for personal oral hygiene and effective plaque removal. A ppropriate toothbrush care and maintenance are al so important considerations for sound oral hygiene. As early as 1920, Cobb reported that toothbrushes could be source of repeated oral infection. ${ }^{1}$ Retention and survival of microorganisms on toothbrushes represent a possible cause of contamination of mouth. Toothbrushes used regularly become contaminated with microorganisms, which colonize the oral cavity. ${ }^{2}$ The bacteria, fungi, viruses can grow and multiply on toothbrush bristles, handles. The area of toothbrush in which tufts are anchored is especially prone to contamination. ${ }^{3}$ Fluid and food debris can be drawn into the spaces between tufts by capillary action and this may lead to bacterial growth. ${ }^{4}$ Microorganisms are everywhere in our environment and thrive in cool dark places, the type of places people store their toothbrushes. Toothbrushes kept in moist environment like that of bathroom, with its traditional, uncovered spot in bathroom are one of the hot spots for fecal bacteria and germs spewed into air by aerosol effect. ${ }^{5}$ Indeed Gerba's studies shown that water droplets in an invisible cloud travel 6 to 8 feet out and up, so the areas of bathroom not directly adjunct to the toilet are still contaminated. ${ }^{6}$ O ral cavity is home to hundreds of different types of microorganisms therefore it is not surprising that some of these microorganisms are transferred to toothbrush during the use. So the main aim of this study was to find which microbial flora is predominantly present on toothbrushes.

\section{MATERIALS AND METHODS}

The data of this study was collected in 2007. One hundred and fifty different used toothbrushes were collected from oral and systemic heal thy population for analysis of bacterial flora in their toothbrush. The present study was conducted in Periodontology Department al ong with collaboration with microbiological department of Pravara Institute of M edical Sciences, Loni, M aharashtra, India.

\section{Protocol followed for Sample Collection}

The toothbrushes were collected from both male and female, and in all age groups. Screening questionnaire examination was performed to rule out presence of any oral and systemic disease. Place of storing toothbrush, frequency of brushing, time period of toothbrush use was also recorded. Toothbrushes were collected only during morning hours to avoid drying of bristles. Collected toothbrushes were put in sterile plastic bags for immediate transfer to microbiology laboratory.

\section{Protocol followed for Microbiological Analysis}

Collected samples of toothbrushes were first dipped (head down) in Robertson cooked meat (RCM), both for analysis of aerobic and anaerobic flora. A fter 24 hours incubation of RCM in incubatory from the superficial portion of the tube, inoculation was done on B lood agar and M acConkey's agar plate. Further incubated for 24 hours and then from the colony morphology, biochemical reactions, the 
organisms was identified. ${ }^{7}$ W hile after 48 hours of incubation of thesame RCM from deeper portion or where meat particles are there, inoculum was taken and put on B lood agar which contains neomycin, vitamins $\mathrm{K}$, and hemin that incubated the plates for 48 hours in anaerobic jar. The colonies were identified and biochemical reactions performed by standard techniques.

\section{RESULTS}

Results showed the presence of aerobic and facultative anaerobes (Table 1), anaerobic bacteria (Table 2) and polymicrobial flora (Table 3). The results were expressed in cell forming unit cfu/ml.

Table 1: Aerobic growth/facultative anaerobic growth

\begin{tabular}{lcl} 
No. & No. of samples & Microorganisms detected \\
\hline 1 & 24 & $\begin{array}{l}\text { Pseudomonas } \\
2\end{array}$ \\
21 & $\begin{array}{l}\text { S. mutans, Coagulase-negative } \\
\text { Staphylococci (CoNS) }\end{array}$ \\
3 & 06 & Diphtheroid \\
4 & 03 & S. sanguis, Micrococci, CoNS \\
\hline
\end{tabular}

Expressed in cell forming unit cfu/ml

Table 2: Anaerobic growth

\begin{tabular}{lcl} 
No. & No. of samples & Microorganisms detected \\
1 & 09 & Bacteroides \\
2 & 06 & Lactobacilli \\
3 & 15 & Leptotrichia \\
\hline
\end{tabular}

Expressed in cell forming unit cfu/ml

\section{Table 3: Polymicrobial growth}

\begin{tabular}{ccl} 
No. & No. of samples & Microorganisms detected \\
\hline 1 & 30 & $\begin{array}{l}\text { S. mutans, Coagulase-negative } \\
\text { Staphylococci, Micrococci, Leptotrichia }\end{array}$ \\
2 & 36 & $\begin{array}{l}\text { S. mutans, Coagulase-negative } \\
\text { Staphylococci, Lactobacilli }\end{array}$
\end{tabular}

Expressed in cell forming unit cfu/ml

\section{DISCUSSION}

In this day of organ transplant and al teration of immune system, it is important to consider toothbrush as a source of potential pathogen. It is clear from the above facts that all of the presently available toothbrushes have the ability to be infected by a wide range of microorganisms, including microbial flora that grow well on toothbrush. Given the fact that very often people will traumatize themselves with their toothbrush, their trauma may become a potential portal entry for organisms. So, it is apparent that present toothbrushes which were basically designed years back need to be re-eval uated. ${ }^{8} \mathrm{~T}$ oothbrush may even have bacteria on them right out of the box. ${ }^{9}$ Thenew FDA approved innovative devices like Dental A ir Force homedental cleaning system will emerge as a true alternative for conventional toothbrushing in regular practice. ${ }^{10}$ The manufacturer recommends twice a day usage for 5 minutes as a part of the regular oral hygiene. The appliance uses a precision jet of air to deliver water and dental cleaner to 'power wash' the mouth. Dental Air Force uniquely dispenses the dental cleaner by you controlling the amount of cleaner that is dispensed in your mouth. One normal application uses one teaspoon of dental cleaner. The cleaner ingredients include sodium bicarbonate, the most widely accepted and totally natural buffering agent that promotes a neutral environment. It also contains mint flavoring, xylitol and stevia as natural sweeteners. The formula is free of sodium laurel sulfate, the ingredient in most toothpaste that causes sensitivity and irritation. Dental A ir Force home dental cleaning system with access to subgingival area lead to removal of biofilm and prevent further proliferation of periodontopathic microorganisms as compared to toothbrush.

\section{REFERENCES}

1. Cobb CM , T oothbrush as a source of repeated oral infections in the mouth. Boston M ed J 1920;183:263-69.

2. Taji SS, Rogers AH. The microbial contamination of toothbrushes: A pilot study. A ust Dent J 1998;43:128-30.

3. Bienenbraeber V , Sponholz H, Hagin J. Characteristics of bristle end rounding and anchoring in brand new and used adult's toothbrushes (in German). Dtsch Zahnarztl Z 1995;50:517-24.

4. A Ithaus D, Kockapan C, W etzel WE. B ristle end rounding and anchoring in children's toothbrushes (in German). Schweiz M onatsschr Zahnmed 1990;100:159-64.

5. Thompson K. H arvard Gazette book review-Overkill. K imberly Thompson. Harvard Gazette A rchives 2002.

6. Gerba CP, Wallis C, Melwick JL. Appl Environ M icrobiol 1975;30(2):771-80.

7. M ackie and M CC artney's. Practical medical microbiology (14th ed). In: College J G, Fraser A G, M armion BP, Simmons A (Eds). N ew Y ork: Churchill Livingstone 1996:501-19.

8. Saini R, Saini S. M icrobial flora on toothbrush: A t greater risk. A nn Nigerian M ed 2010;4:31-32.

9. Glass RT, Lare MM. Toothbrush contamination: A potential health risk. Quintessence Int 1986;17:39-42.

10. Saini R. Periodontal health 2020: The future outlook. Int J Experiment Dent Sci 2012;1(2):V.

\section{ABOUT THE AUTHORS}

\section{Rajiv Saini (Corresponding Author)}

A ssistant Professor, D epartment of Periodontology, Pravara Institute of M edical Sciences, A hmednagar, M aharashtra, India, Phone: +91-9923206789, e-mail: drperiodontist@yahoo.co.in

\section{Varun Kulkarni}

General D entist, Patil D ental Care, M umbai, M aharashtra, India 